\title{
Analysis of the Improvement of Highlights Education Performance Productivity Based on Balanced Scorecard (BSc) Method
}

\author{
Ade Tutty \\ $\left\{\right.$ adetuttyrosa@uninus.ac.id $\left.{ }^{1}\right\}$ \\ Study of R \& D at the Institute of Domestic Governance (IPDN), Universitas Islam Nusantara, \\ Bandung, Indonesia ${ }^{1}$
}

\begin{abstract}
To review the education system; performance productivity, vision and mission of quality institutions; a strategy is needed that can communicate various interests to provide quality assurance in a comprehensive and balanced manner. The core problem of the research is the analysis of the implementation of the Employment and Accountability Evaluation Education. Its performance is still static, especially in the Higher Education Skills (IPDN. This writing is prepared on the basis of the Balanced Scorecard Method (BSC) and Maps Strategy (Kaplan and Northon, 1996). (BSC) as a management system composed of four different perspectives (Financial, Customer, Internal Process Business, Learning \& Growth), to realize the effectiveness of educational performance and reliably measured performance productivity. Triangulation research methods Mixed method design data transformation model, which interpreted as qualitative, each devendent Variable, indevendent Variable, statistical application, regression analysis analysis, path analysis, research findings there were significant differences and major influences between the four BSC perspectives in the implementation of education in IPDN; some aspects of Service Error Rate means that it is not balanced, so that there is balance and harmony with the research objectives, the formulation and translating of all the results programmed into the Maps strategy are interpreted into the BSC strategy so that a causal design and Omax matrix can be created that create new strategies.
\end{abstract}

Keywords: Performance productivity, IPDN, Balanced ScoreCard..

\section{Introduction}

One of factor government failed service institution education, low education quality, cause the goal could not measure and not reall also education institution in empowering and effectivity function system in doing evaluation system performance productivity in each institution so there is gap in national education standard in education actuating ,performance productivity ,institution vission and mission, need tool for measuring and strategy for communicating, quality assurance , comprehensive and balance.core of problem in higher education. This research try to explain institution higher education actuating in IPDN, based on education system change, performance productivity, service quality, vission mission strategy base on balance score card and Maps strategy 


\section{Background Problems}

This paper is an illustration of the results of the author's research, in the 2010-2011 school year in higher education the Institute for Domestic Governance (IPDN) Jatinangor Sumedang Profinsi West Java. The contents in the description of the results of the study are trying to elaborate on the design of the implementation of higher education in the field of leadership based on educational adjustments; Teaching, Training and parentingperformance productivity, vision, mission, goals and strategies at IPDN at that time, were analyzed with one concept or theory from Kaplan and Northon, 1996. namely a Balanced Scorecard (BSC) measurement method and Maps strategy.

This paper is described at this time based on the following considerations:

Results of interviews with the top management (Governor Chancellor of IPDN on January 11, 2017; Academic Bureau, Bureau of Employment and Planning ; as a partial review of the results of previous research, which in essence is:

(1) it is very supportive once the results of previous studies will be re-published at this time concerning the productivity of performance and related education implementation components in the science of government in the Balanced Scorcard measurement system is very relevant in IPDN. Besides that, the existence of cooperation in the relationship of the research communication network with stakeholders is very supportive of the crdibility and imaging of research institutions in IPDN; (2) the results of the author's research from the BSC measurement system on the implementation of education in IPDN have not been fully fulfilled, meaning that it has never been tested especially on the productivity system of teaching and training teaching performance using the BSC measurement method; (3) The performance measurement system still uses the Government Science Performance Accountability Report (LAKIP), although there are some changes in the performance system of teaching, training and care; (4) The results of research on measurement methods with the BSC method, in Higher Education IPDN are still relevant and can be used in several divisions, especially in the Jarlatan system which still has to be developed, which is adjusted to the current vision, mission, goals and strategies contained in IPDN. (5) The need for innovative development transformed from a measurement system into an education management system in government science.(6) The educational management process built around multidimensional Balanced ScoreCard enables alignment and concentration of long-term strategic implementation that must be carried out appropriate and made the basis of good and professional management in IPDN in this information century; (7)The description of the results of the research for now can be used as an example of ways or methods of measuring the education management system and productivity system of teaching performance training as well as care for an educational institution such as IPDN ".

Thus the description of research results at IPDN, in this paper is still very relevant and can be used according to the needs and objectives to be achieved in the development of education and productivity of teaching and nurturing teaching performance in other IPDN or education, also expected to be used as a reference or an example measurement in the implementation of education using the BSC method for the next or other relevant researchers. So the writer raises and rearranges the core of the results of the description of this research as follows:

"(1) National education policies and implementation that use Education Production Factor, namely input, output, outcomes that are not implemented consistently. This is because it is too imposing on the quality of the input to pay less attention to the quality of the process, even though the quality of the process greatly determines the quality of education output; (2) The implementation of education is carried out in a centralistic bureaucratic manner, which is very dependent on bureaucratic decisions which are very long lines sometimes the policies issued are 
not in accordance with the conditions in the field / local; (3) the participation of education citizens is less supportive in the delivery of education so that it inhibits various aspects in improving the quality of education as well as the quality of performance, whereas in accordance with the functions and objectives of national education (2003), every citizen has the right to receive education equally with excellence and balancing (equity) between utilization (access) and achievement "

One system instrument in administering education in government institutions that can be offered to trigger education development, without departing from scratch, is to do: revitalize government resources. Revitalization of education in government institutions to achieve competitive advantage means that the role of education is believed to be very important and strategic, but because the management of its resources is not or is not good, the competitive advantage of education in Indonesia is low. The solution is how to revitalize education resources in these government institutions so that competitiveness becomes high.

For the sake of the realization of good education and government, which is oriented towards achieving national goals (referring to democratization in the life of the state with constituent elements such as legitimacy, accountability (accountability), securing of human rights, autonomy and devolution of power and assurance of civilian control having competencies, structures, political mechanisms, functioning effectively is professional education organized by non-departmental government departments or institutions, which are expected by various parties to fulfill access to equity, competitiveness of Indonesian education that must be fought for by the nation. among them must have good governance skills, which are based on the principle of accountability (accuntability).

\section{Research Urgency}

The problem faced when the study was carried out, in the Ministry of Home Affairs's education administration institutions, namely the Domestic Government Intitute (IPDN) were: "There are differences in the implementation of education systems with the National Education Standards (SNP) in several aspects. In its implementation, the determination of performance indicators carried out in accordance with the guidelines for the preparation of government agency LAKIP (LAN RI, 2006), "the performance of government organizations is measured quantitatively and qualitatively by using input indicators, outputs, outcomes. , benefits, and impacts. the emphasis is more on "the results of" underestimating the process ".

According to several previous studies including in Karso's research, 2010 at PTN (UPI and UIN West Java) stated that:

"The Government Performance Accountability Report, known as LAKIP as a media of accountability that contains the performance of government agencies, which is useful, among others, to encourage good governance must be carried out by PTN which must refer to applicable laws and regulations, it has a level of processing accuracy and data analysis. relatively low. The institutional management performance accountability calculation only calculates the amount and in detail only for the performance of its activities. Further analysis of performance accountability not described in this type of performance accountability has been developed since 2002 ". The performance measurement system using these indicators has weaknesses, including that measurements are only carried out on the basis of internal organizational assessment, no community participation indicators / applicable standardization, in the assessment process. Static". 
The reality in practice in the study illustrates that the greatest weakness of government performance lies in the components of the process. In addition, measurement of financial and non-financial performance is still carried out separately. Then identified about the analysis of the Implementation of Education and evaluating Productivity / Performance Accountability does not have a performance evaluation standard that is carried out continuously for several aspects, namely still using a measurement system with Lakip (Performance Accountability Report of Government agencies). These two issues in research in Higher Education The IPDN's expertise in becoming a focus of research is considered crucial.

Because of the need for an accountable evaluation measurement standard as an evaluation of the accountability of the performance reports of higher education ministries of the interior such as IPDN with a standardized evaluation that is coherent, comprehensive, balanced and measurable; the need for a design / matrix that can provide balance in the education system with productivity performance, which is a tool that can help in seeing whether the under control process or not by seeing a common cause of variation or special causes of variation. The tools for this are the control chart in the Balanced ScorCard (BSC) Method and controlling the limitations of the BSC using the Maps strategy model, which is a standardized measurement for the balance of managing long-term strategies, and ultimately this system is able to meet and satisfy stakeholder needs with the participants' mentality and character students (praja) who are built in an integrated and friendly manner.To bridge the weaknesses of the above problems, especially in the performance accountability evaluation system, the authors look at the possibility of application studies through a review of concepts / theories developed by Kaplan Robert and Norton (1996). on the education system and performance productivity, through the Balanced ScoreCard (BSC) Method. The theory as a tool is stated as asTraslating vision and four Perspectives: Financial, Customer, Internal Business Process, Learning and Growth strategies.Aspects of planned research based on the BSC method and Maps Strategy, in its analysis and discussion are carried out on aspects of the education and government processes related to: (1) Aspects of education implementation based on SNP; (2) Organizing aspects include (Vision, mission, institutional strategy); (3) aspects of performance productivity (organizational culture, nurturing care system, performance satisfaction and accountability reporting of government agencies) in IPDN, as well as other aspects as a companion to research.

\section{Formulation and Limitation of Problems}

The formulation and limitation of the problems in this study are as follows:

1. Are the four perspectives of BSC (Financial, Customer, Internal Process, Learning \& Growth) able to formulate and translate the implementation of education on IPDN ;

2. Is there any influence between the education component in the BSC concept on performance productivity (work services and job satisfaction) in IPDN?;

3. Is there a balance between the four perspective Balanced Scorecard (BSC) components in the delivery of education and performance productivity in improving the quality of education and the quality of performance services on IPDN?

4. Are the results of the interpretation of the implementation of education and performance productivity on the quality of performance teaching services, training and care, can be designed to produce a new strategy in the form of a quality of service performance especially in higher education of IPDN expertise? performance manual, as one of the education 
management models in performance productivity, and the quality of service performance especially in higher education of IPDN expertise?

The formulation and limitation of the problem can be described as follows:

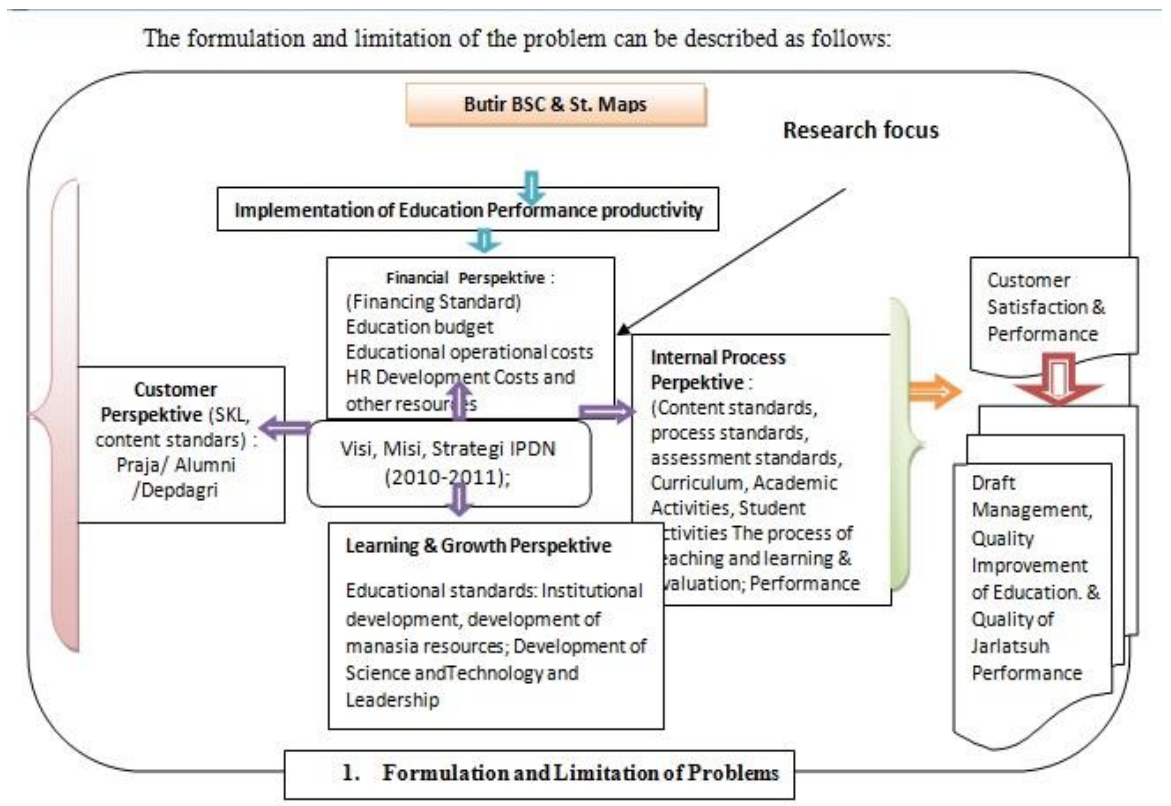

Fig 1. The formulation and limitation of the problem

From the picture above it can be explained that in the analysis of education implementation there are several factors / aspects that influence its success.

\section{Research Objectives and Benefits}

The results of this study, are expected to benefit theoretically, academically and practically, in the world of education, especially in IPDN educational institutions, reviewing to see the feasibility and suitability of the system, strategies, and programs that are running with the conditions being faced and the future; It can also be used as a consideration by the authorities especially for the strategic functions in improving the quality of education and the quality of performance services, as well as community services that are in line with the Vision, Mission and goals; evaluate the performance productivity and service quality of jarlatsuh; consideration in the performance appraisal system including the management of Praja mentality development, as a policy to produce quality civil service, especially in the IPDN environment.

Research Data Grouping in terms of the Balanced Scorcard, scorecard method can be seen in the following table: 
Table 1. Grouping of research object judging from the balanced scorecard method

\begin{tabular}{|c|c|c|}
\hline \multicolumn{3}{|c|}{ Organizing Education \& Performance Productivity at IPDN } \\
\hline \multirow{3}{*}{$\begin{array}{l}\text { No } \\
1 \\
\end{array}$} & \multicolumn{2}{|c|}{ Componen/ Perspective } \\
\hline & Financial & Purpose \\
\hline & $\begin{array}{l}\text { 1. Educational \& teching budget for training } \\
\text { and care } \\
\text { 2. Cost of education / education } \\
\text { management } \\
\text { 3. Costs of developing human resources and } \\
\text { other resources }\end{array}$ & $\begin{array}{l}\text { 1. Improve the quality of education } \\
\text { 2. Increase activity ratio } \\
\text { 3. Increase liquidity ratio } \\
\text { 4. Improve resources \& facilities infrastucture }\end{array}$ \\
\hline 2 & Internal process & \\
\hline & $\begin{array}{l}\text { 1. Curriculum, PBM \& evaluation } \\
\text { 2. Academic activities } \\
\text { 3. Operational innovation } \\
\text { 4. Educational services } \\
\text { 5. Culture performance / health of the } \\
\text { organization } \\
\text { 6. Academic \& leadership activities }\end{array}$ & $\begin{array}{l}\text { 1. Improving the quality of education services } \\
\text { 2. Increased creativity, innovation in the } \\
\text { teaching and learning process } \\
\text { 3. Quality improvement of service performance } \\
\text { teaching, training and care } \\
\text { 4. Qualty improvement of jarlatsuh coaching } \\
\text { services }\end{array}$ \\
\hline 3 & Customer & \\
\hline & $\begin{array}{l}\text { 1. Praja / learners } \\
\text { 2. Employement activities } \\
\text { 3. Praja recruitment / acceptance } \\
\text { 4. Praja life rules / graduates }\end{array}$ & $\begin{array}{l}\text { 1. Maintain \& imrove the quality of graduates } \\
\text { 2. Improving institutional ability customer needs } \\
\text { 3. Improve accountability and imaging }\end{array}$ \\
\hline 4 & Learning \& Growth & \\
\hline & $\begin{array}{l}\text { 1. Institutions \& bureaus; lecturer / } \\
\text { education } \\
\text { 2. Education staff / staff } \\
\text { 3. Infrastructures } \\
\text { 4. Worker capability \& worker retention } \\
\text { 5. Information system capability } \\
\text { 6. Motivation, empowerment and harmony }\end{array}$ & $\begin{array}{l}\text { 1. Improven \& development of institution, HR } \\
\text { (lecturers, managers, staff, caregiver, trainers } \\
\text { and other resources personnel) } \\
\text { 2. Increased satisfaction of performance } \\
\text { improving service quality of jarlatsuh } \\
\text { performance } \\
\text { 3. Performance loyalty, enhanced partnership }\end{array}$ \\
\hline 5 & Vision, mission and strategy & $\begin{array}{l}\text { 1. Translating the vision, mission and } \\
\text { institutional strategies in strategic planning } \\
\text { 2. Formulating strategies in } 4 \text { BSC perspective } \\
\text { and maps strategies } \\
\text { 3. Creating a new strategy in the form of matrix }\end{array}$ \\
\hline 6 & Performance productivity & \\
\hline & $\begin{array}{l}\text { (work culture, lecturer performance, } \\
\text { management performance, job satisfaction) }\end{array}$ & $\begin{array}{l}\text { Improving the quality of services \& coaching } \\
\text { performance in teaching and nurturing teaching }\end{array}$ \\
\hline
\end{tabular}

\section{Merging Qualitative Data Results and Qualitative data results}

The results of quantitative data, each of which is interpreted into the Balanced ScorCard method through four perspectives (Financial, Customer, Internal Process and Learning \& Growth) on Quality Management in the implementation of education in government science, (Education system, Organizing system, KBM system) and Performance Productivity (teaching, training and PBM) to get the quality of graduates / quality of education is getting better and increasing. 
Quantitative results and qualitative data are interpreted through the Vision, Mission and Strategy of educational institutions. The formulated and translated by the Balanced ScoreCard Method in each Perspective to get a causal design between education / education system management and performance service productivity system, which will then be translated by each BSC perspective through Maps Strategy (Opration Management, Innovation, regulation \& Social, Vision, Mission and Goal in the form of the Omax Matrix so as to produce an Action Plan (Target, Initiative and Budget), which can be used as a comprehensive, coherent, measurable and balanced Management Draft of PTS in West Java that is used as a research focus.

\section{Literature review}

\subsection{The Balanced ScoreCard method according to Anthony, Banker, Kaplan, and Young (1997):}

Balanced scorecard method is : a management, measurement and control system that quickly, accurately and comprehensively directs organizational performance. An organization uses the scorecard measurement focus to produce important management processes, namely: clarifying and translating the vision and mission, communicating and linking various goals and strategic measures, planning, setting goals, and aligning various strategic initiatives, as well as increasing feedback from strategic learning into various objectives, measures, which are organized into four perspectives, namely: financial, customer; internal business; learning and growth. Four scorecard perspectives provide a balance of short and long-term goals; between the results and the driving factors of the process dimension; person ; and internal / external dimensions. BSC in higher education means in government management is how to move an organization to achieve a goal, how a tool to control or oversee achieving a goal and be logical

\subsection{The Maps Strategy means}

The Maps Strategy means that the use of the Balanced ScoreCard is a set of hypotheses regarding causal relationships that are transformed in the measurement of relationships (hypotheses) that exist in various destinations in explicit perspectives so that they can be managed and validated, and the causal chain must cover all perspectives of the Balances ScoreCard. The functions and advantages of the Maps Strategy in the Balanced Scorecard method can bring about improvements in: cost reduction, performance productivity improvements; Growth in market share, customer retention, reduction in cycle time; Product ( service) development systematic method, parameter data collection; determine the source of variation and how to eliminate; contains unity of purpose; directed at planning. vision, mission, goals, goals so that they are fully integrated and clear; the BSC in its Developers functions as an analitycal tool to help solve problems".

\subsection{Performance productivity in reviewing the BSC at IPDN}

Performance productivity in reviewing the BSC at IPDN is: A measure of results, the overall impact of efforts to improve morale and expertise in performance, innovation, internal processes, and good satisfaction in service quality education and its contribution to service in 
the community. The aim is to compare the output produced by all elements related to the quantity of performance that is deployed to produce the output.

\subsection{The essential candidates and bureaucrats in the IPDN environment}

The essential candidates and bureaucrats in the IPDN environment are: is the formation of mentality, intellectual and transformation of knowledge received by Praja emphasizes more on systematic and structured constructs that are transferred through logical reasoning to form a complete personality with a balance of science, faith. and education in charity through the process of transformation and internalization of Islamic knowledge and values in Praja through the growth and development of its natural potential to achieve the balance and perfection of life in its optimal aspects and the development of a positive mentality / morality is a reflection of the intellectual.

\section{Description of Research Results}

The data on the education implementation system (teaching system, training system and care system) that is interpreted to the Balanced SorCard Method is not comprehensive and unbalanced in several perspectives, because there are several indicators that cannot be aligned or have very significant differences, especially in the internal perspective of the process and development learning \& Growth, so it needs to be analyzed further by formulating and translating Vision, mission and strategy into the BSC strategy with the Maps Strategy model, to clarify the objectives achieved.

\section{Balance Analysis between BSC perspectives}

The results are shown by Path analysis results of statistical calculations in the implementation of education in IPDN as follows:

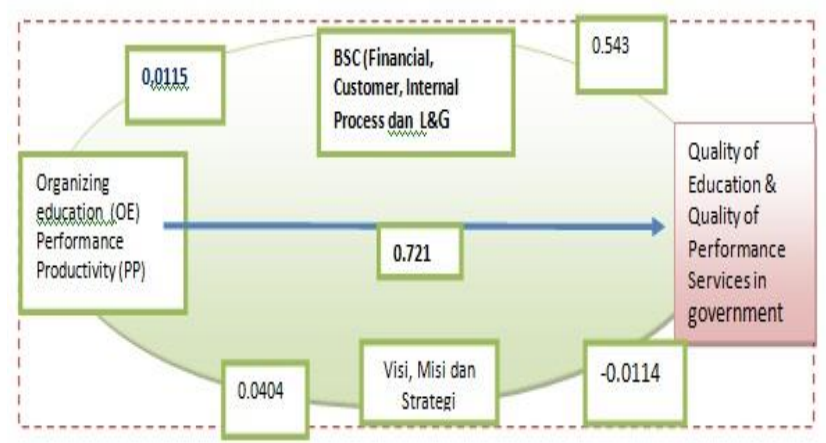

Fig 2. Path Analysis Diagram

Note :

A balance of four perspectives on the implementation of Education through Performance Activities.Path between the implementation of education has a Path value of 0.6432.The path between PP and OE has a Path of Education 0.6756 .The path between MPDS and OE through EP has a path of -0.2568 


\section{Results of analysis discussion on the implementation of education on performance productivity.}

\subsection{Discussion of Internal Research Results (Performance Productivity at IPDN)}

Based on the results of the data analysis of the Education System (in the BSC concept) Education generally increases, it can be seen from the average score for each indicator of each perspective, besides that it can be seen from the comparison of the average score for each indicator and can also be seen from the criteria Perspective of learning \& Growth (Growth and learning) results in overlaving (unbalance between each perspective). The following is a diagram for improving the Implementation of Education System with performance productivity in government. A small percentage of respondents on average $(070.00 \%)$ stated strongly agree and almost half the average $(024.10 \%)$ said they agreed that the BSC method was very.

\subsection{Achievement of Average Percentage of Ability Score Through 4 Perspective BSC}

Table 2. Average Score of the Education System in terms of the BSC Method in IPDN (Focus Research

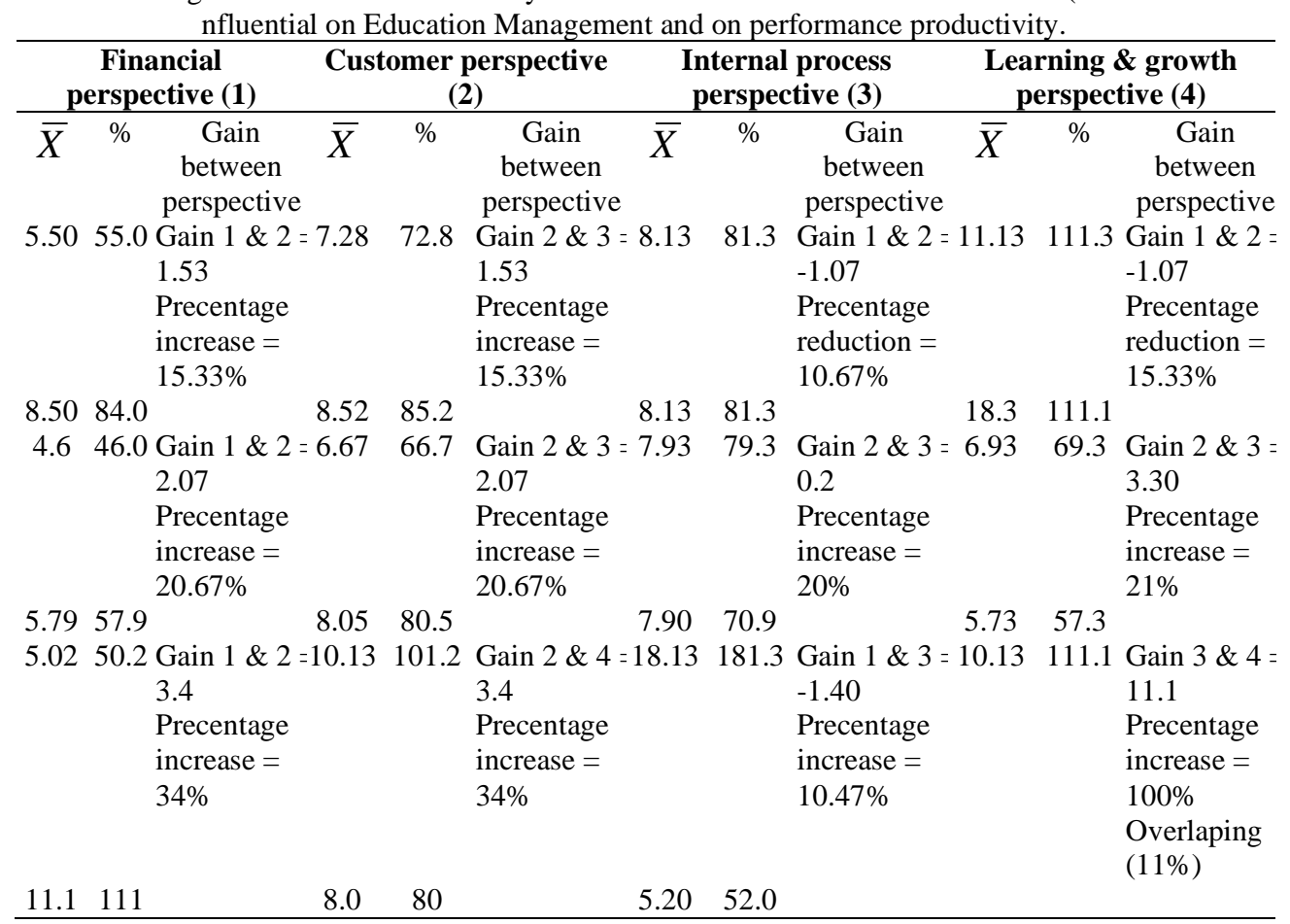




\section{Description of Results Questionnaire}

Based on the data obtained from calculations in the education system for performance productivity for each perspective obtained an overview of the average score questionnaire stated in the table as follow :

Data on Average Score and Average Percentage of Each Financial Perspective .

Table 3. Data on average score and average percentage of each financial perspective indicator

\begin{tabular}{lcc}
\hline \multicolumn{1}{c}{ Indicator } & Average score & Average percentage \\
\hline Fluency (education budget) & 7.2 & 70.2 \\
Flexibility (education operational costs) & 8.30 & 80.3 \\
Elaboration (human resource deelopment costs) & 5.89 & 50.83 \\
Originality (other resource development costs) & 5.0 & 50.0 \\
\hline
\end{tabular}

Table 4. Data on average score gain and average percentage of each customer perspective indicator

\begin{tabular}{lcc}
\hline \multicolumn{1}{c}{ Indicator } & Average score & Average percentage \\
\hline Fluency & 9.1 & 90.1 \\
Flexibility & 5.6 & 50.6 \\
Elaboration & 7.4 & 70.4 \\
Originality & 6.5 & 60.5 \\
\hline
\end{tabular}

Table 5. Data on average score of each perspective indicator internal business process

\begin{tabular}{lcc}
\hline \multicolumn{1}{c}{ Indicator } & Average score & Average percentage \\
\hline Fluency (curriculum) & 17.2 & 170.3 \\
Flexibility (academic activities) & 15.09 & 156.09 \\
Elaboration (student activities) & 17.03 & 170.2 \\
$\begin{array}{l}\text { Originality (teaching and evaluation learning } \\
\text { process) }\end{array}$ & 16.66 & 160.60 \\
\hline
\end{tabular}

Table 6. Data on average score of each learning and growth indicator

\begin{tabular}{lcc}
\hline \multicolumn{1}{c}{ Indicator } & Average score & Average percentage \\
\hline Fluency (education budget) & 8.30 & 93.0 \\
Flexibility (education operational costs) & 8.53 & 94.2 \\
Elaboration (human resource deelopment costs) & 7.15 & 80.1 \\
Originality (other resource development costs) & 7.00 & 66.0 \\
\hline
\end{tabular}

\section{Quantitative research results performance productivity}

Pathway (Parth Analysis) the relationship between the components of educational implementation in the BSC perspective (variable $\mathrm{X}$ ), on performance productivity in IPDN (variable $\mathrm{YB}$ ), to improve the quality of service performance (Z). As the answer to hypothesis 2 with the results of Path analysts as follows: 


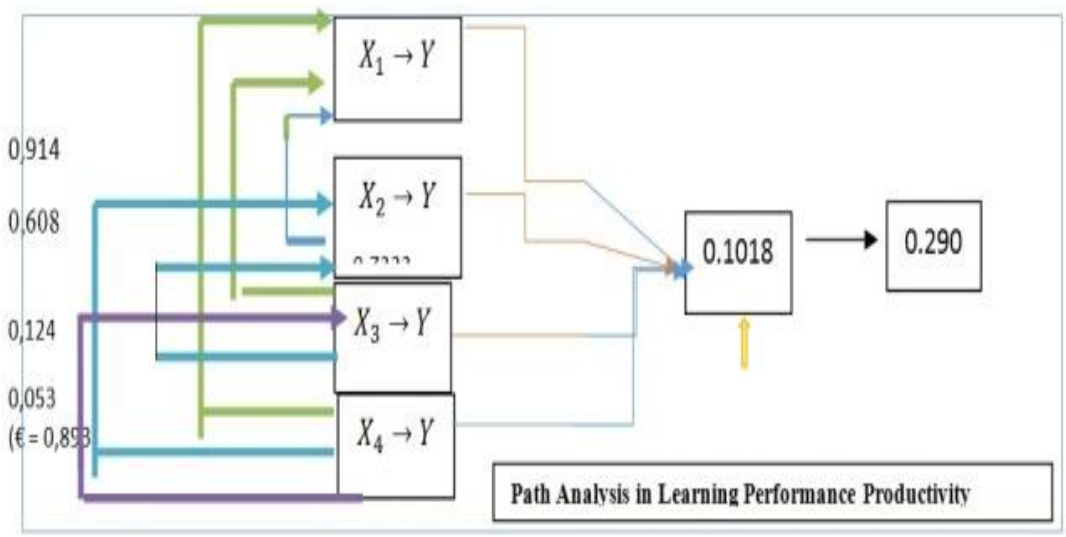

Fig 3. The results of Path analysts

Based on the results of calculating the effect of variable $\mathrm{X}$ on the performance productivity variable (Y_2), using Path Analysis / Figure 5, it is known that the Financial variable (0.0914); Customer $(0,608)$; internal process $(0.124)$ and learning \& growth $(0.053)$ education gives a positive value, this means that it is significant to the performance productivity variable (Y_2 = $0.1018)$, namely there is a large influence on each perspective and error rate $(€=0.893)$. Thus, it shows that: there is a correlation between the implementation of education (YES) in Perspective BSC (X) and performance productivity (YB), this means that the higher the degree of correlation, the better and better service quality performance of Jarlatsuh at IPDN. Besides that performance and satisfaction have a positive relationship, then three views suggest: (1) satisfaction causes performance / vice versa; (3) disturbing rewards (intervene), and there is no inherent relationship. The existence of an appreciation of the work will provide motivation to carry out all demands, related to the work means testing the hypothesis is accepted.

\section{Conclusion}

Based on the results of the processing and analysis of the research data, there is a significant difference in the normalized gain between education providers and performance productivity, in improving the quality of education with quality service performance, but the response to the education system and performance system in IPDN has a positive response. Because in the system given at IPDN there is a characteristic as one of the education systems referring to constructivism in the formation of characteristics with a better purpose. The arguments that can be raised from this research, especially in higher education which is used as the focus of research, namely higher education of IPDN are as follows : (1) There is a balance and harmony in the implementation of education, a performance productivity system using the Balanced Scorecard and Maps strategy methods, and based on the basic values of education, it can improve the quality of education, objective and transparent performance accountability; (2) Vision, mission and strategy can be formulated and translated in accordance with the management principles of the BSC strategy and the Maps strategy model, can design causal loop diagrams (causal diagrams) which are translated into omax matrix, can be used as a 
strategic plan or a the right draft education management, especially in Higher Education IPDN Management.

\section{Practical Implications}

\subsection{Consists of several practical implications that need attention and include:}

First, in order for the evaluation system in the implementation of education and performance productivity system to be reviewed based on the BSC Method and the Maps Strategy that is applied (analyzed does not lose its soul, is understood and internalized by the entire academic community at IPDN in particular, it is necessary to establish appropriate educational quality ethics. with basic values, both religious, moral, ethical, sientific (logic) and aesthetic values which form the basis for thinking and acting to achieve the goals and objectives to be achieved. In order to achieve effective and targeted goals and objectives of the BSC method and Maps strategy, it needs to be designed and built based on the results of the survey on needs (professional needs, social needs and industrial needs), the results of self-evaluation and internal audit. Because the results of the survey or the results of the study reduce the gap between graduates and community needs.

Second, because of the concept of the four perspectives in the Balanced Scorecard with the development of a Maps Strategy, giving a framework, language, to communicate the mission and strategy; through academic services that are cultivated by academicians, IPDN is expected to foster the image, trust and motivation for its customers to continue to contribute and participate in the educational process at IPDN. On the other hand, BSC as a powerful approach of a management system composed of four perspectives (financial, customer, internal process, and learning and growth) is expected to overcome the problems of institutional IPDN.

Third, teaching training and careand Praja supervisors and the community: it is expected that human resources and community resources as a process of actualizing the potential of educational resources, can overcome various obstacles to the development of creativity and inventivity, which is more important and very urgent in the quality of service performance guidance jarlatsuh towards praja is ethics that must always be number one as a control of the possibility of arrogance and physical control during care by caregivers and senior cadets to their juniors. Although in the framework of the formation of a strong physical and mental personality, but still the control of communication ethics is prioritized, especially when communicating in the form of physical touch. in order to improve the quality of education management, improve the quality of jarlatsuh's performance services specifically in the IPDN official higher education institutions.

Fourth, researchers in the fields of education and government management and in government politics: (1) are expected to develop an evaluation / measurement system of performance accountability in the implementation of education and performance productivity, using the Balanced ScoreCard Method developed with the Maps Strategy Model; Six Sigma Model; Dynamic System Model; Government ScoreCard or other models, through further research to be more entrenched, easily implemented in the field and have an impact on the goals to be achieved; (3) for the next researcher, this research can be developed again to explore other 
aspects related to the evaluation / supervision / review / measurement system in the field of education and government, especially at the high IPDN Institutions.

\subsection{Recommendation}

The realization in IPDN, besides paying attention to the above recommendations, is also expected as soon as possible to perfect, improve and develop the Jarlatsuh system, in accordance with the stated Chancellor of IPDN (Nyoman.S, interview results in March 2012) which is essentially about the balance of the current system of value changes such as democracy, transparency and more. integrated in the whole system in accordance with the essential functions of government given in IPDN. In addition, it is expected to be realized, the jarlatsuh system in the integration of service, development, empowerment in the aspects of brand, aspects of training and soft aspects). Also related to the supervision system, HR in the development of Jarlatsuh to implementation,bureaucracy, management, quality assurance and IT development as well as other aspects. On the other hand BSC as a powerful approach of a management system composed of four perspectives (financial, customer, internal process, learning and growth) with the development of the Maps Strategy Model is expected to overcome the problems of institutional IPDN.

Thus the need for transparency and adjustment of various managerial aspects of education, especially in improving the quality and service of education, for each of its activities and citizens are expected to have a fully integrated future leadership spirit, kaffah is a mentality fostering, intellectual transformation of knowledge received emphasizes systematics and constructitism arranged that is transferred through logical reasoning power to form a complete personality with a balance of science, faith and charity in education through the process of transformation and internalization of Islamic knowledge and values to customers, through the growth and development of its natural potential to achieve optimal balance and perfection of life. Besides that, it is demanded to have basic values in character building including quality first, mode of existence, ihsan value, itqan, creativity and integrity innovation. It is expected that the role of education to be strategic and balanced for all aspects of the quality management process of education, implementation and performance productivity, to improve national competitiveness and build independence, mutual strength as a nation, sourced from national ideology, adhered to by all components of the nation's reform and organizational transformation. This is in line with SanusiAchmad's view, namely 5 basic values that become the reference of actions, thoughts and behavior of his organization, namely: (a) Theological value (divine), (b) use teleological value, (c) scientific value, (d) ethical values, (e) aesthetic values (f) physiological and ethic values that also need to be considered, because ethics is a "body of principle" that directs people to do something right and in accordance with the norm values make it is as a driving force for higher education in realizing their respective higher education vision, mission, goals and strategies, including higher education, IPDN skills, namely institutions that provide public services, improve the Quality of Education and Quality of performance services and uphold the image of the institution. an Educational Institution that provides new social formations, which are important elements in strengthening social cohesion. Thus, higher education in particular can provide an important contribution to efforts to strengthen integration, so that it becomes a Great Nation in this country. 


\section{References}

[1] Allen,Bogdan, Robert and Biklen, (1992)."Qualitative Research For Education An Introduction to Theori and Methodes". Boston: Allyn an Bacon, Inc.

[2] Cohen, Stephen \& Ronald Brand, (1993). "Total Quality in Government, (In Ikke's Dissertatio DewiSartika, Total Quality of STPDN", 1999), PPS IKIP Bandung.

[3] Freddy Rangkuti, (2000). "Swot Analysis of Business Case dissecting techniques", Gramedia Jakarta

[4] Giroth. Lexie. M, (2002), "the impact of public policy on official education performance", Desertation, UPI Bandung

[5] Kaplan, Robert S. and David P. Norton. (1996). "Translating Strategy Into Action: The Balanced Scorecard:", Massachusetts: Harvard Business School Press..."Implementing the Strategy to Be an Action" (2000) Balanced Scorecard".

[6] Mulyadi. (2007). "Integrated System for Managing Personnel Performance Based on Balance Scorecard”.Yogyakarta: UPP STIM YKPN UGM.

[7] Rydzak, F., et. al., "Journal of Teaching the Dynamic Balanced Scorecard", [Online].

[8] Sanusi, Achmad. (2000). "Education System Information Management'. PPS Uninus Bandung... . (2007). Teaching Unit: SIM and Strategic Education Quality Management

[9] Sa1is,E,(2008). Total Quality Management in Education. Jogyakarta: IRCiSod.

[10] Taliziduhu . Ndraha. (1996)." Government Science Methodology", Professor Inauguration Speeches remain on Institute of Government Sciences, Jakarta.

[11] Wasistiono, Sadu. (1997). 21st Century Civil Service Leadership, Scientific Speeches are delivered in Order of the Anniversary of STPDN VII, Jatinangor

[12] Yuwono, Sony., Sukarno, Edy., Ichsan, Muhammad., 2006, Practical Guide to BSC Preparation:Towards A Strategy-Focused Organization, Gramedia Library. 